\title{
THE LEAHBER DEARG, OR RED BOOK OF CLANRANALD.
}

Notice of the ancient Gaelic MS., termed "The Little Book of Clanranald," communicated by W. F. Skene, Esq., F.S.A. Scot.

From the evidence collected by the Highland Society in 1805 , with reference to the authen ticity of Ossian's Poems, Mr Skene shewed that a small MS., termed sometimes the "Red Book," and sometimes the little book of Clanranald, was given by MacVurich of South Uist, the last of the hereditary Senachies of Clanranald, to Macpherson, the so-called translator of Ossian. MacVurich, in his declaration, says it was called the Red Book, was made of paper, and was given to James Macplerson; that he had others written on parchment, and that both were in the old Gaelic character, and like a Bible. Ewen Macpherson, who was with James Macpherson when he received it, says, it was a book of the size of a New Testament, that it was not the Red Book, and that a folio MS. called the Red Book, was in the possession of a Lieutenant Donald Macdonald, in Edinburgh. The minister of the parish, Mr Angus $M \cdot N e i l l$, also present, states, on the other hand, that the folio MS. in Edinburgh was a transcript made by Clanranald himself, of a MS. which had been stolen and taken to Ireland. When Macpherson died, only one old MS. was found among his papers, and this was the one he had obtained from MacVurich. It is mentioned by Malcolm Laing in his work upon Ossian. It was afterwards copied by $\mathrm{Mr}$ Donald Mackintosh, librarian to the Highland Society of London, and his copy having since been acquired by Mr Skene, was produced to 
the meeting. Mr Mackintosh calls it a " copy of the small volume (erroneously called) the Leahber Dearg of Clanranald, beginning at page 33, the rest are gone;" he has added at the end the following synopsis of its contents :"The principal part of this MS. consists of a history of the Clan Macdonald, beginning with Angus $\mathrm{Og}$, Lord of the Isles, who fought on the side of Robert Bruce at Bannockburn, and terminating with the wars of Montrose. This account is interspersed with a few genealogies, and with several poems, but these are all poems of a comparatively late date, and laudatory of the clan and its chiefs. There are none attributed to Ossian in the MS." It was from this copy that a very loose and inaccurate translation was furnished to Sir Walter Scott, and whence he derived some of the notes to the "Lord of the Isles." $\mathrm{Mr}$ Skene likewise produced a few leaves of an ancient paper MS., which, from the nature of the contents, he believed to form part of the earlier portion stated by $\mathrm{M}$ 'Intosh to be lost. The original MS., borrowed by James Macpherson, eventually came into the possession of the late Hugh Macqueen, W.S., as agent for Clanranald, and was produced by his successor, for inspection of the Society on this occasion, who had only that morning discovered it among Clanranald's papers. Mr Skene assigned reasons for believing that this MS. is not the original "Red Book," but an ancient copy. He then proceeded to detail the circumstances attending his discovery and ultimate acquirement of another ancient and more perfect copy of the same MS. in Dublin; which contains the whole of M'Intosh's copy, and the earlier portion wanting in it, including in it the few leaves which $\mathrm{Mr}$ Skene had previously supposed to form part of it. This MS. he also exhibited, and stated his reasons for believing both to be eopies of the original MS. called the Leahber Dearg, or Red Book of Clanranald, kept by the MacVurichs, the hereditary Senachies of the family, and of which transcripts were made from time to time. The Irish copy is in the ancient Gaelic character, has been added to at different periods, and contains the entire genealogy, of which thirty-two pages are wanting in the other MS. In the evidence formerly quoted, the Rev. Angus M'Neill describes one of the MSS. referred to, as the copy of an older one which had been carried off to Ireland. Mr Skene concluded his remarks by expressing the pleasure he felt in helieving that this interesting MS. has again revisited Scotland, after so long an interval; and stated his intention of depositing it, under certain conditions, in the Advocates' Library, along with the other Gaelic MSS. of that national collection. In the course of his remarks, $\mathrm{Mr}$ Skene shewed the very slight grounds which had sufficed to satisfy those who spoke from recollection of the "Little Book of Clanranald," that it was really an Ossianic MS. The Lord of the Isles is termed in it Righ Fiongall, King of Fingal, a poetical expression 
for the Western Isles; and the clan of the Macdonalds is ealled Clan Colla. The recollection of these two names seems to have been accepted by certain over-zealous champions for the honour of this Homeric era of the Gael, as evidence enough of a poem, the subject of which was the wars of the renowned Fingal of Ossian and his father Combal.

Mr Skene then read a translation of a part of the MS. giving a curious account of the expulsion of the Danes from the west coast of Scotland. 